\title{
CANCELAS INVISÍVEIS: “EMBARGOS AURICULARES”, LEGITIMIDADE ATIVA E A PERMEABILIDADE SOCIAL SELETIVA DO SUPREMO TRIBUNAL FEDERAL ${ }^{1}$
}

\section{INVISIBLE GATES: PRIVATE HEARINGS, STANDING AND THE SELECTIVE SOCIAL PERMEABILITY OF THE BRAZILIAN SUPREME COURT}

Juliana CeSARio Alvim GOMES²

RESUMO: O artigo argumenta que, apesar da retórica utilizada por seus ministros, a permeabilidade social do Supremo Tribunal Federal opera de maneira seletiva, impedindo o acesso de certos grupos ao tribunal ao mesmo tempo em que o franqueia a outros. Essa seletividade social se manifesta por meio de diversos mecanismos formais e informais amparados em regras processuais e regimentais e em práticas procedimentais aparentemente neutras. $\mathrm{O}$ artigo analisa dois desses mecanismos, que são pouco ou nada debatidos pela literatura nacional: a jurisprudência restritiva acerca das entidades autorizadas a proporem ações no controle abstrato de constitucionalidade e a prática de audiências informais privadas entre advogados e partes e ministros, conhecidas como "despachos". A distribuição desigual das vias de acesso ao STF vai de encontro não apenas à noção de acesso à justiça, mas também às ideias de igualdade, democracia e, no limite, do próprio Estado de Direito.

Palavras-Chave: Supremo Tribunal Federal; Seletividade Social; Permeabilidade social; Legitimidade Ativa; Acesso à Justiça.

\footnotetext{
${ }^{1}$ Agradeço a Diego Werneck Arguelhes, Felipe Recondo, Jane Reis Gonçalves Pereira e Ligia Fabris Campos pela interlocução e comentários ao manuscrito. Agradeço a Judith Resnik pela supervisão durante a realização de pesquisa sobre audiências informais privadas entre advogados e partes e magistrados no Brasil que deu origem à sessão correspondente no presente artigo. A Lorena Senra Freitas e Gabriel Teixeira Guia agradeço pela obtenção e sistematização dos dados sobre os despachos no STF.

2 Professora Adjunta da Faculdade de Direito da UFMG. Doutora e mestre em Direito Público pela UERJ. LL.M. pela Yale Law School. Contato: julianacesarioalvim@ufmg.br.
} 
Abstract: The paper claims that, despite the rhetoric of its justices, the social permeability of the Brazilian Supreme Court is selective: access to the court is provided to certain social groups, but not to others. The social selectivity of the court operates through formal and informal mechanisms based on procedural rules that are seemingly neutral. The article analyzes two of such mechanisms that are barely (or not at all) addressed by existing scholarship: the restrictive case law on standing to bring abstract constitutional review challenges, and the practice of informal private hearings between attorneys, parties, and justices, known as despachos. The paper argues that the unequal distribution of access to the court goes against the ideas of access to justice, equality, democracy and the rule of law itself.

Keywords: Judicial Review; Due Process; Social Permeability; Social Selectivity; Private hearing.

\section{INTRODUÇÃo}

A atuação do Supremo Tribunal Federal sofre de um paradoxo. Enquanto o tribunal ativamente esforça-se para apresentar-se como uma Corte aberta e em diálogo com a sociedade, essa abertura opera de maneira socialmente seletiva: acessível a uns e não a outros. Em outras palavras, a permeabilidade do STF à sociedade é seletiva e essa seletividade se manifesta por meio de mecanismos formais e informais.

O paradoxo da permeabilidade do STF reflete-se na sua jurisprudência com relação aos direitos de minorias: de um lado, o tribunal julgou relevantes casos relativos a direitos de grupos minoritários, como as ações afirmativas de cunho racial, as uniões homoafetivas e o aborto de fetos anencefálicos. De outro, esses grupos enfrentam enormes obstáculos para acessar o tribunal ${ }^{3}$. Por exemplo, nenhum dos casos acima referidos foi levado ao STF pelas próprias minorias interessadas. Foram sempre outros atores - um partido político, um governador de estado e a Procuradoria Geral da República, e a Confederação Nacional dos Trabalhadores na Saúde, respectivamente. Ao invés de levarem sua própria voz e suas próprias causas ao Supremo, os movimentos sociais precisaram "mascarar" seus pleitos dentro das regras do processo constitucional. Silenciados por essas regras, falavam por meio de outros atores.

É inegável que, mesmo nesse cenário, nesses e em outros casos, minorias políticas conseguiram alcançar vitórias importantes por meio da jurisdição constitucional. Entretanto, até para as histórias de sucesso, o acesso limitado e seletivo à Corte produz efeitos negativos: perda de seu protagonismo, restrição de seus argumentos, sujeição de suas causas a composição e barganhas com seus

\footnotetext{
${ }^{3}$ A esse respeito, veja-se a definição de acesso de Brooke Coleman (2009, p. 264): “Acesso significa a oportunidade de alcançar o mérito de uma demanda jurídica. Mais especificamente, eu defino acesso de modo a significar que o esforço de um litigante para alcançar uma resolução jurídica não deve ser obstruído por obstáculos processuais que indevidamente acarretem desvantagens para um grupo de litigantes em relação a outro". (tradução livre).
} 
"representantes" oficiais. Isso sem falar nas demandas que chegam à Corte sem qualquer respaldo de seus principais interessados ou que sequer alcançam a jurisdição constitucional.

Além da porta de entrada formal, regras de funcionamento do tribunal também criam obstáculos para o acesso de grupos marginalizados ao STF. Os despachos que ocorrem entre representantes das partes e ministros é um deles. Embora previstos em lei como um direito dos advogados, não existe regulamentação sobre como devem operar. Na prática, ocorrem de maneira informal e privada, a critério de cada ministro. Além disso, não são registrados nos autos dos processos, ocorrem sem a participação da parte adversa e nem sempre dentro dos gabinetes. A falta de transparência e equanimidade com que se desenvolvem faz com que essas audiências privadas funcionem como uma barreira oculta que separa aqueles que terão seus "embargos auriculares" apreciados daqueles que não.

A questão da legitimidade para a propositura de ações no controle abstrato de constitucionalidade e os chamados embargos auriculares não são, contudo, os únicos mecanismos de seletividade social do STF. Inúmeras normas e práticas podem funcionar como cancelas invisíveis que condicionam de maneira desigual o acesso ao tribunal: regras processuais, linguagem utilizada, práticas cotidianas. Até mesmo a exigência de certos trajes, ao recaírem de maneira diferenciada sobre diferentes grupos sociais, beneficiando uns em detrimento de outros, funciona como empecilho ao acesso à Corte. Só no final da década de 1990 mulheres foram autorizadas a entrar no tribunal vestindo calças compridas (FOLHA DE SÃO PAULO, 1997). Ainda hoje é necessário "traje social" para entrada na sala de julgamentos ${ }^{4}$. Para os gabinetes, o traje varia, porém, as exigências não são disponibilizadas no portal eletrônico do tribunal e quem as aplica são as recepções dos respectivos prédios ${ }^{5}$. Além da incerteza que o procedimento gera, a imposição desses requisitos tem o potencial de excluir, por exemplo, estudantes uniformizados ou grupos sociais que utilizam suas roupas como parte de suas identidades, como minorias étnicas.

Em comum, esses múltiplos mecanismos de seletividade social assentam-se em normas processuais e procedimentais a princípio neutras, mas que, na prática, discriminam e excluem estratos sociais em regra já marginalizados. Ao mesmo tempo, beneficiam grupos em geral já dotados de influência e proeminência econômica, política e social. Nesse contexto, a análise da abertura seletiva do STF que ora se propõe pressupõe, nas palavras de Jane Reis Gonçalves Pereira (2016, p.

\footnotetext{
${ }^{4}$ Consta da sessão "Perguntas Frequentes" acerca de audiências públicas no portal do Supremo Tribunal Federal: "Os homens deverão trajar terno completo (blazer, calça social, camisa social, gravata e sapato social) e as mulheres, calça, saia ou vestido sociais, necessariamente acompanhados de blazer". Disponível em <http://www.stf.jus.br/portal/cms/verTexto.asp? servico=audienciaFaq\&pagina=Perguntas_frequentes $>$. Acesso em 22 de junho de 2019.

${ }^{5}$ Em 25 de fevereiro de 2019, o portal Migalhas (2019) publicou fotografia de tabela afixada na portaria do Supremo Tribunal Federal listando os gabinetes dos ministros e o respectivos trajes exigidos para o acesso a cada um deles, que se dividiam entre "livre", "social - não é permitido calça jeans nem camisa sem manga" e "social completo - homem: terno e gravata; mulher: terninho inclusive com vestido". Há, ao fim do documento, observação adicional "gabinete do ministro Dias Toffoli - em caso de visitante com traje social incompleto, ligar no gabinete antes de liberar o acesso".
} 
144), "reconhecer e debater a dimensão política das normas processuais" 6 ou, ainda, conforme colocado por Judith Resnik (1989), seu "conteúdo político e [su]as consequências"7. Ampara-se, igualmente, na ideia de que direitos fundamentais são ou deixam de ser promovidos por cortes constitucionais não apenas por meio de decisões de mérito, mas também por meio de suas práticas (GOMES, 2016, p. 652-676).

À luz disso, o presente artigo busca avançar nesse debate ao analisar a distribuição desigual da abertura e do acesso ao Supremo Tribunal Federal. Essa ideia será sintetizada ao longo do artigo por meio das expressões permeabilidade social seletiva e seletividade social do STF. ${ }^{8}$ Para tanto, serão analisados dois mecanismos por meio dos quais esse fenômeno se opera. O primeiro é a jurisprudência acerca da legitimidade para a propositura de ações no controle abstrato de constitucionalidade, tema que nos últimos anos vem recebendo progressiva atenção da literatura jurídica e da própria jurisprudência do STF. O segundo, até agora inédito, consiste na prática de audiências informais privadas entre ministros e partes e/ou seus representantes, os chamados despachos ou, ironicamente, embargos auriculares. A escolha dos objetos se justifica tanto pelo fato de serem pouco ou nada explorados na literatura nacional quanto em razão da possibilidade de sua modificação e aprimoramento pelo próprio STF.

\section{PORTA DE ENTRADA - JURISPRUDÊNCIA RESTRITIVA ACERCA DA LETIGIMIDADE ATIVA PARA PROPOR AÇÕES NO CONTROLE ABSTRATO DE CONSTITUCIONALIDADE}

O artigo 103 da Constituição Federal de 1988 elenca os legitimados para propor ações no controle abstrato de constitucionalidade perante o Supremo Tribunal Federal $^{9}$. A ampla lista contrasta com a tradição anterior que limitava essa

\footnotetext{
${ }^{6}$ A autora assinala ainda que "No Brasil, o direito processual é debatido e ensinado nas universidades sob um foco predominantemente procedimental, com pouca reflexão sobre sua faceta política e sobre os impactos econômicos que as fórmulas processuais encerram. Há uma carência de análises que investiguem a fundo as preferências políticas e os interesses corporativos e econômicos que as regras de processo promovem".

${ }^{7}$ Sobre o tema veja-se também Minow (1998, p. 101-132), Cover (1975, p. 718-740) e Burbank (2004).

${ }^{8} \mathrm{O}$ termo "seletividade" foi previamente utilizado, em outro contexto, em referência ao STF para descrever a preferência do tribunal por certos temas em detrimento de outros ao compor sua agenda por Carvalho (2005, p. 146) e Lima (2013, p. 207). No presente artigo, contudo, as expressões "permeabilidade social seletiva" e "seletividade social" denotam, para além da preferência por determinadas temáticas, o acesso diferenciado de certos indivíduos e grupos ao tribunal. A seletividade temática e a permeabilidade social seletiva STF são dois fenômenos que se relacionam, mas que não se confundem.

9 Art. 103. Podem propor a ação direta de inconstitucionalidade e a ação declaratória de constitucionalidade: I - o Presidente da República; II - a Mesa do Senado Federal; III - a Mesa da Câmara dos Deputados; IV - a Mesa de Assembléia Legislativa ou da Câmara Legislativa do Distrito Federal; (Redação dada pela Emenda Constitucional no 45, de 2004); V - o Governador de Estado ou do Distrito Federal; (Redação dada pela Emenda Constitucional no 45, de 2004); VI - o Procurador-Geral da República; VII - o Conselho Federal da Ordem dos Advogados do Brasil; VIII
} 
prerrogativa ao Procurador Geral da República ${ }^{10}$. Apesar da intenção constituinte de ampliar o acesso ao controle abstrato de constitucionalidade em um contexto de redemocratização, o STF estabeleceu por meio de sua jurisprudência uma série de restrições que passaram a limitar o acesso à jurisdição constitucional.

Com efeito, a perspectiva dos membros do tribunal, contrária a um modelo de controle de constitucionalidade com acesso mais amplo, foi manifestada mesmo antes dos trabalhos da Assembleia Nacional Constituinte. Como documenta Diego Werneck Arguelhes (2014, p. 31), os ministros do STF, em mensagem enviada em 1986 à Comissão Afonso Arinos recém-convocada para elaborar um projeto de Constituição, declararam oficial e publicamente que a legitimidade ativa para arguir inconstitucionalidade de lei ou ato normativo deveria permanecer exclusivamente com a Procuradoria Geral da República.

Alinhado a essa visão pré-constitucional, o STF, composto em sua maioria por ministros nomeados antes de 1988, passou a limitar, por meio de sua jurisprudência, o alcance do amplo rol do artigo 103 incluído na nova Constituição. Nesse sentido, restringiu a abrangência da categoria "confederação sindical", passando-a a concebê-la de modo a excluir sindicatos e federações sindicais e, sem que houvesse qualquer previsão constitucional para tanto, impôs a exigência de "pertinência temática" para alguns dos legitimados exigindo-lhes uma conexão entre o objeto da ação e seus objetivos sociais. ${ }^{11}$

Adicionalmente, passou a entender "entidades de classe de âmbito nacional", previstas no o inciso IX do referido artigo, como apenas aquelas de caráter econômico e profissional, excluindo quaisquer outras modalidades de entidades. Sobre esse aspecto, a compreensão do STF se baseou em uma leitura corporativa do vocábulo "classe" calcada em diplomas normativos desenvolvidos meio século antes, como a CLT. No julgamento da ADI 42, em que originalmente se decidiu a questão, o ministro Sepúlveda Pertence assim sintetizou o argumento:

Assim, valendo-se, mutatis mutandis, das definições legais do art. 511, CLT, entidades de classe serão as associações cuja base social e cuja orientação finalística partam, ou (a) da pressuposta "solidariedade de interesses econômicos dos que empreendem atividades idênticas, similares ou conexas" (categoria econômica ou empresarial) ou do reconhecimento dos interesses comuns derivados (b) do exercício da mesma atividade profissional ou de profissões similares ou conexas ou ainda, finalmente, (c) do

- partido político com representação no Congresso Nacional; IX - confederação sindical ou entidade de classe de âmbito nacional.

${ }^{10}$ Dispunha a Constituição de 1967, em seu art. 114 que "Compete ao Supremo Tribunal Federal: I processar e julgar originariamente: 1) a representação do Procurador - Geral da República, por inconstitucionalidade de lei ou ato normativo federal ou estadual;"

${ }^{11}$ Para um levantamento da jurisprudência do STF sobre o tema veja-se Guimarães (2009). 
trabalho em comum, ainda que em profissões diversas, na mesma atividade econômica ou em atividades econômicas similares ou conexas. ${ }^{12}$

Não obstante ter apoiado a tese vencedora no caso concreto, referido ministro consignou a contradição presente na interpretação retroativa do STF ao assinalar que "o novo texto fundamental quis efetivamente fazer a grande válvula de abertura e descentralização social da iniciativa do controle direto da constitucionalidade das leis" e que

a interpretação mais adequada àquela regra será a que dê ao conceito de 'entidade de classe de âmbito nacional' toda abrangência que ela comporte, sem violência, de modo a estender a legitimação ao maior plexo possível de associações representativas de setores significativos da estrutura plural da sociedade (...). ${ }^{13}$

Na ocasião, contra a interpretação restritiva do inciso IX do artigo 103, ficaram vencidos os ministros Celso de Mello e Célio Borja, que, respectivamente, consignaram:

Justifico ainda meu voto, senhor Presidente, pelo receio que tenho de que uma interpretação restritiva da locução constitucional em análise - como a preconizada pela douta Procuradoria-Geral da República - possa limitar o exercício, pelo Supremo Tribunal Federal, no instante mesmo em que se busca tornar efetivo e real o princípio da universalidade da tutela jurisdicional, da mais expressiva, fundamental e relevante competência que lhe outorgou a Assembleia Nacional Constituinte: a guarda e defesa da Constituição.

\footnotetext{
${ }_{12}$ Voto do Min. Sepúlveda Pertence em STF, ADI 42/DF, Pleno, Rel. Min. Paulo Brossard, julg. 24.9.1992.

${ }_{13}$ Voto do Min. Sepúlveda Pertence em STF, ADI 42/DF, Pleno, Rel. Min. Paulo Brossard, julg. 24.9.1992, parágrafo 31. Posteriormente, por ocasião de outros julgamentos, o mesmo ministro explicitou sua divergência com relação à jurisprudência restritiva: “De outro lado - considerando que a legitimação para a ação direta de inconstitucionalidade das 'entidades de classe de âmbito nacional' é a abertura mais significativa do acesso da sociedade civil ao controle abstrato de normas - sou dos que ainda resistem à tendência de reduzir o alcance da inovação ao âmbito puramente corporativo das classes profissionais ou econômicas, a rigor, já contemplado, no mesmo inciso IX do art. 103 da Constituição, com a legitimação das confederações sindicais". STF, ADI 894-MC/DF, Rel. Min. Néri da Silveira, Pleno, julg. 19.11.1993.
} 
a classe não é um numerus clausus de atividades e interesses, identificados e classificados pelo Estado, como no corporativismo estado no vista; mas, para compatibilizar-se com uma Constituição que põe entre os objetivos fundamentais da República a construção de uma sociedade e livre e solidária (art. 3o, I,), deve a classe ou categoria ser espécie ou gênero de interesses que as pessoas elegem, a cada momento, e para cuja a defesa ou fomento se submetem à disciplina societária que melhor lhes pareça.

Com base na posição vencedora, o STF firmou sua jurisprudência e rejeitou o acesso à jurisdição constitucional por parte de diversas organizações, como a Associação Brasileira de Consumidores ${ }^{14}$, Associação dos Ex-Combatentes ${ }^{15}$, Associação Brasileira de Defesa do Cidadão - ABRADEC ${ }^{16}$ e a União Nacional dos Estudantes - UNE. ${ }^{17}$ Além disso, em razão desse "estreitamento dos canais de acesso"18, outras entidades deixaram de acionar o controle abstrato de constitucionalidade, ainda que tivessem plena identificação com a causa em questão e representatividade social.

Nesse contexto, diversas das mais celebradas decisões relativas a direitos fundamentais tomadas pelo STF nos últimos anos só foram possíveis em função do ocultamento de seus defensores mais legítimos. Na Arguição de Descumprimento de Preceito Fundamental no 54, relativa ao aborto de feto anencefálico, houve uma decisão deliberada de propor a ação por meio de legitimados que não suscitassem maiores questionamentos à luz da jurisprudência do STF (BARROSO, 2013, p. 331332). Nessa ação, a iniciativa da causa teve origem em entidade de defesa do direito das mulheres, o Instituto de Bioética, Direitos Humanos e Gênero - ANIS. Em virtude da impossibilidade de sua aceitação como legitimada, foi feita pesquisa na jurisprudência do STF entre todas as entidades que já haviam sido admitidas como legitimadas, buscando uma cujo objeto tivesse relação a causa, até que se chegou à

${ }_{14}$ STF, ADI 1693, Pleno, Rel. Min. Marco Aurélio, julg. 23.10.1997.

${ }^{15}$ STF, ADI 2073, Pleno, Rel. Min. Moreira Alves, julg. 09.03.2000.

${ }_{16}$ STF, ADI 61, Pleno, Rel. Min. Sepúlveda Pertence, julg. 29.8.1990.

${ }^{17}$ STF, ADI 894-MC, Pleno, Rel. Min. Néri da Silveira, julg. 19.11.1993.

${ }^{18}$ A expressão é de Pereira (2016, p. 143). A autora pontua ainda que "Ter uma causa decidida pelo STF não é uma empreitada fácil. No âmbito da jurisdição abstrata e concentrada, o acesso é limitado, primeiramente, pela lista de legitimados enunciada na Constituição e, em acréscimo, pela interpretação restritiva formulada pelo próprio STF. Na jurisdição constitucional difusa, fazer um Recurso Extraordinário chegar ao tribunal não é simples, seja pelos vários requisitos para a correta formulação jurídica da peça, seja pelas dificuldades operacionais de acompanhar o recurso e o julgamento no Distrito Federal. Ao mesmo tempo, a prática judiciária nos tribunais superiores é marcada pela presença de uma advocacia de elite altamente especializada, que atua sobretudo nas questões com relevância financeira e não está acessível para os grupos marginalizados. A verticalização da jurisdição constitucional, em última análise, tornou a proteção dos direitos fundamentais mais distante dos seus titulares". 
Confederação Nacional dos Trabalhadores na Saúde - CTNS (BARROSO, 2013). A estreita relação do caso com a luta das mulheres evidencia-se na própria petição inicial, em que se indica que a ANIS forneceu apoio técnico e institucional para a elaboração da ADPF, solicitando, de pronto, sua admissão como amicus curiae.

No caso das uniões homoafetivas, foram necessárias decisões processuais estratégicas que, ao mesmo tempo em que viabilizaram o julgamento das ações, acabaram por mascarar a atuação do movimento, que sempre esteve presente. A ADPF n⿳0 132, ajuizada em 2008, teve por autor o Governador do Estado do Rio de Janeiro, Sérgio Cabral. Para que pudesse ser proposta, foi preciso que os juristas envolvidos em sua elaboração identificassem uma questão estadual afeta à causa, de modo a cumprir a exigência de "pertinência temática" imposta pelo Supremo para os chamados "legitimados não universais", como os governadores. ${ }^{19}$ A ADI n 4.277, por sua vez, embora tenha se originado de representação elaborada pelo Grupo de Trabalho em Direitos Sexuais e Reprodutivos do Ministério Público Federal em parceria com diversas organizações do movimento LGBT, foi proposta somente em nome da Procuradoria Geral da República, que é considerada pela jurisprudência do STF como legitimada universal, não tendo, portanto, que demonstrar pertinência temática. ${ }^{20}$ Note-se que sua propositura só foi possível em 2009 em função do exercício interino do cargo pela Vice-Procuradora Geral Deborah Duprat, tendo em vista que o Procurador Geral da República já havia, em momento anterior, optado por não propor a ação (BARROSO, 2013, p. 421-423). A subprocuradora Deborah Duprat, aliás, em um cenário de bloqueio aos movimentos sociais, foi indispensável para o avanço da agenda de direitos humanos no âmbito do STF, sendo responsável, em apenas um mês, pelo ajuizamento de diversas ações no controle concreto de constitucionalidade, relativas aos seguintes temas: mudança de nome de transexuais sem cirurgia de transgenitalização (ADI no 4.275), não criminalização das "marchas da maconha" (ADI no 4.274), regularização fundiária da Amazônia (ADI no 4.269), ingresso e permanência de cães-guia em locais públicos e privados (ADI no 4.267), regulamentação da profissão de músico (ADPF $\mathrm{n}^{\mathbf{0}} 183$ ). ${ }^{21}$

Tanto no caso do aborto de feto anencefálico quando das uniões homoafetivas, durante a elaboração das ações, estiveram envolvidas entidades representativas dos interesses em jogo - respectivamente, entidades de mulheres e da população

\footnotetext{
${ }^{19}$ Como conta Luís Roberto Barroso (2013, p. 422), que foi advogado no caso, a solução encontrada foi apontar que o interesse do Governador estaria em determinar se as uniões homoafetivas estariam contempladas nas previsões de licença de servidor em função do cônjuge e de benefícios previdenciários para familiares de servidor previstos pelo Decreto-Lei estadual n. 220, de 18.07.1975, Estatuto dos Servidores Civis do Rio de Janeiro.

${ }^{20}$ As organizações foram: ABGLT - Associação Brasileira de Gays, Lésbicas, Bissexuais, Travestis e Transexuais; Associação da Parada do Orgulho dos Gays, Lésbicas, Bissexuais e Transgêneros de São Paulo; IDENTIDADE - Grupo de Ação pela Cidadania Homossexual; e Corsa Cidadania, Orgulho, Respeito, Solidariedade e Amor.

${ }^{21}$ Esse levantamento encontra-se em Leite (2014).
} 
LGBT. Entretanto, no momento da propositura da ação, foi necessário mascarar a demanda com a indumentária institucional, acionando-se os legitimados à luz da jurisprudência restritiva do STF, sem que as entidades representativas das categorias em questão pudessem elas próprias veicular seus entendimentos constitucionais. Em causas de fundamental interesse para os movimentos sociais, que tocam nos fundamentos mesmos de sua existência, sua atuação teve de se dar, em um primeiro momento, de maneira sub-reptícia.

A subordinação de seus interesses a intermediários, por sujeitarem-nas a ponderações externas e a todo tipo de barganha, frequentemente leva à perda de sua autonomia no processo (VIANNA, 1999, p. 105). Isso pode implicar não só restrição de argumentos, mas perda de protagonismo e respaldo social. Além disso, a necessidade de mascaramento por meio de intermediários pode levar a uma excessiva demora para que determinada questão chegue ao STF. Isso sem falar daquelas que sequer alcançam a jurisdição constitucional em razão das referidas restrições jurisprudenciais.

Por outro lado, atores corporativos com forte influência política e econômica costumam ter franqueado o acesso às vias institucionais de acesso à jurisdição constitucional para fazer valer seus interesses, seja porque preenchem os requisitos impostos pela jurisprudência do STF, seja por terem maior facilidade em cooptar certos legitimados para que os representem. Tal visão é corroborada por pesquisa coordenada por Juliano Zaiden Benvindo e Alexandre Araújo da Costa que constatou que, em função de seus legitimados ativos, sobretudo partidos políticos, governadores de estado e o Conselho Federal da OAB, prevalecem, entre as ações diretas de inconstitucionalidade julgadas pelo Tribunal, as que têm por objeto a garantia de interesses institucionais ou corporativos, em detrimento dos direitos fundamentais (COSTA, 2013).

Desde o início da década de 1990, vozes dissonantes no STF $^{22}$ e, mais recentemente, fora dele ${ }^{23}$ têm se manifestado contrariamente à leitura restritiva do rol de legitimados para propositura de ações no controle abstrato de constitucionalidade. Desde então, a própria jurisprudência do Tribunal já sofreu mitigações, como a que levou à mudança do entendimento que negava a legitimidade a "associações de associações"24. Em 2015, em sede de decisão monocrática na ADI 5291, o ministro Marco Aurélio reconheceu a legitimidade do Instituto de Defesa do Consumidor - IDECON para ajuizar ação no controle

\footnotetext{
${ }^{22}$ Veja-se, a título de exemplo, o referido voto do Min. Sepúlveda Pertence na STF, ADI 894-MC/DF, Rel. Min. Néri da Silveira, Pleno, julg. 19.11.1993 e os relevantes votos dos ministros Célio Borja e Celso de Mello na ADI 42/DF, Pleno, Rel. Min. Paulo Brossard, julg. 24.9.1992.

${ }^{23}$ Gomes $(2014,2016)$, Freire (2015, p. 591-640), Sarmento (2017), Ferreira e Geraige Neto (2018, p. 101-133), Brandão e Nunes (2018, p. 164-196) e Leite (2018, p. 217-224).

${ }^{24}$ STF, ADI 3.153 /DF, AgR, Pleno, Rel. Min. Celso de Mello, Rel. p/ Acórdão: Min. Sepúlveda Pertence, julg. 12.8.2004.
} 
abstrato de constitucionalidade. ${ }^{25}$ Em 2018, também em sede monocrática, o ministro Roberto Barroso admitiu como legitimada ativa a Associação Brasileira de Lésbicas, Gays, Bissexuais, Travestis e Transexuais ("ALGBT") em ação versando sobre parâmetros de acolhimento de LGBTs submetido à privação de liberdade nos estabelecimentos prisionais brasileiros. ${ }^{26}$

As decisões, contudo, ainda não ensejaram um movimento amplo do tribunal, permanecendo em vigor o entendimento que limita as entidades de classe a categorias profissionais e econômicas. Como consequência, perdura, sob argumento aparentemente técnico, a desequiparação de certas entidades perante outras. Na ausência de uma virada jurisprudencial que mude as regras que vem sendo aplicadas pelo STF a essa hipótese, mesmo exceções estabelecidas pela via monocrática ficam sujeitas à discricionariedade dos respectivos relatores e podem acabar sendo, elas próprias, seletivas.

\section{EMBARGOS AURICULARES - AUDIÊNCIAS INFORMAIS PRIVADAS ENTRE ADVOGADOS E PARTES E MINISTROS DO STF}

A distribuição desigual do acesso ao STF também recai sobre vias menos formais, como os despachos com ministros - audiências privadas entre magistrados e advogados ou partes que ocorrem a pedido de uma das partes para discutir um determinado caso. Em regra, os despachos possuem duas características que os definem: são informais, ou seja, não obedecem a qualquer conjunto de procedimentos pré-estabelecidos, tendo seu funcionamento determinado pelo próprio magistrado em questão, e privados, isto é, não são abertos ao público, ocorrendo a portas fechadas, em geral (mas nem sempre) no gabinete dos magistrados e na ausência da parte adversa.

A legislação em vigor considera os despachos um direito do advogado e um dever do juiz. O Estatuto da Advocacia e da Ordem dos Advogados do Brasil $(\mathrm{OAB})$ explicitamente estabelece para os advogados o direito de "dirigir-se diretamente aos magistrados nas salas e gabinetes de trabalho, independentemente de horário previamente marcado ou outra condição, observando-se a ordem de chegada". ${ }^{27}$ Um outra versão desta previsão está presente na Lei Orgânica da Magistratura (LOMAN), de 1979, que estabelece que os magistrados têm o dever

${ }^{25}$ ADI 5291, Rel. Min. Marco Aurélio, julg. 6.05.2015.

${ }^{26}$ MC-ADPF 527, Rel. Min. Roberto Barroso, julg. 29.06.2018. As razões apontadas pelo ministro foram, em síntese: "Em primeiro lugar, as justificativas que levaram o STF a construir uma interpretação restritiva do significado de 'classe' não estão mais presentes. Em segundo lugar, o resultado de tal interpretação implica violação à teleologia e ao sistema da Constituição e impede que o Supremo cumpra uma dimensão fundamental da sua missão institucional: a proteção de direitos fundamentais com celeridade, efetividade e em ampla escala. Em terceiro lugar, trata-se de interpretação que enseja a violação da igualdade por impacto desproporcional sobre grupos minoritários".

${ }^{27}$ Lei no 8.906 , de 4 de julho de 1994 DiÁRIO OficIAL DA UnIÃo [D.O.U.] de 05.07.1994 art. 7, VIII. 
de "atender aos que o procurarem, a qualquer momento, quanto se trate de providência que reclame e possibilite solução de urgência".$^{28}$ Comparada ao Estatuto da Advocacia, a previsão da LOMAN, por um lado, limita os despachos a situações de urgência, mas, por outro, amplia a lista daqueles que podem realizálo para além dos advogados.

Até hoje, questionamentos relativos à prática jamais foram julgados pelo Supremo Tribunal Federal. Desde 2009, contudo, há ação sobre o tema pendente de apreciação pela Corte. Na ADI 4330, a Associação Nacional dos Magistrados Estaduais (ANAMAGES) questiona a constitucionalidade da expressão "independentemente de horário prévio marcado ou outra condição" contida no Estatuto da Advocacia e afirma a necessidade de agendamento prévio e comunicação da parte ex adversa. O Superior Tribunal de Justiça, por sua vez, já teve oportunidade de se debruçar sobre o tema algumas vezes quando da imposição de limitações, por magistrados, ao horário para realização de despachos. ${ }^{29} \mathrm{Em}$ todas essas ocasiões, o STJ rejeitou o limite temporal de acesso aos juízes fazendo referência às previsões legais acima discutidas, sem maiores considerações. O único argumento constitucional por vezes utilizado consistiu na invocação do artigo 133 da CF, relativo à indispensabilidade dos advogados para a administração da justiça. ${ }^{30}$ No mesmo sentido, o Conselho Nacional de Justiça vem determinando a anulação de medidas que limitem dia e horário para atendimento a advogados ${ }^{31}$.

Assim como os debates legislativos que deram origem ao arcabouço legal ora em vigor, os debates judiciais sobre os despachos com magistrados no Brasil têm abordado a questão pelo ponto de vista corporativo, deixando em segundo plano os princípios processuais por trás das disputas profissionais entre juízes e advogados ${ }^{32}$. De um lado, a "dignidade da magistratura", de outro, a "dignidade da advocacia", sem, em regra, enfrentar princípios como o do contraditório, da ampla defesa, do devido processo legal e os deveres de publicidade,

\footnotetext{
${ }^{28}$ Lei no 35, de 14 de março de 1979 DiÁRIO OfiCIAL DA UNIÃO [D.O.U.] de 14.03 .1979 art. 35: “São deveres do magistrado: (...) IV - tratar com urbanidade as partes, os membros do Ministério Público, os advogados, as testemunhas, os funcionários e auxiliares da Justiça, e atender aos que o procurarem, a qualquer momento, quanto se trate de providência que reclame e possibilite solução de urgência".

${ }^{29}$ Por exemplo, RMS 13.262/SC, $1^{\mathrm{a}}$ T., Rel. Min. Garcia Vieira, Rel. p/ Acórdão Min. Humberto Gomes de Barros, julg. 18.06.2002, DJ 30.09.2002, p. 157; S.T.J, RMS 23.796/SC, 1를 T., Rel. Ministro Teori Albino Zavascki, julg. 06.03.2008, DJe 26.03.2008; S.T.J., RMS 18.296/SC, $1^{\underline{a}}$ T., Rel. Min. Denise Arruda, julg. 28.08.2007, DJ 04.10.2007, p. 170; S.T.J., RMS 15.706/PA, 2ª T., Rel. Min. João Otávio de Noronha, julg. 01.09.2005, DJ 07.11.2005, p. 166.

30 ART. 133: "O advogado é indispensável à administração da justiça, sendo inviolável por seus atos e manifestações no exercício da profissão, nos limites da lei".

31 Para uma decisão recente, veja-se: CNJ, Plenário, Pedido de Providências n. 000462026.2016.2.00.0000, Rel. Cons. Daldice Maria Santana de Almeida, julg. 20/02/2018.

32 Para uma análise dos debates legislativos e judiciais veja-se GOMES (no prelo).
} 
impessoalidade e moralidade da Administração Pública. Em outras palavras, o problema, quando discutido, tem sido formulado como um conflito entre corporações, sem que se leve em conta o seu impacto sobre direitos de partes e grupos sociais representados.

Debates legislativos recentes, entretanto, trouxeram novos argumentos para a discussão pública. Em 2013, o projeto de lei n. 6.732 da Câmara dos Deputados requeria o prévio agendamento para as audiências de despacho bem como a notificação do advogado da parte adversa antes da ocorrência desse tipo de reunião. O projeto de lei também estabelecia que, em casos de urgência, a audiência privada poderia ocorrer a despeito de prévio agendamento, caso em que a notificação a outra parte se daria em um prazo de cinco dias. ${ }^{33} \mathrm{O}$ objetivo do PL, segundo sua exposição de motivos, seria evitar "conexões espúrias" entre advogados e magistrados e a frequente interrupção do trabalho dos magistrados, promovendo maior eficiência no Poder Judiciário. O PL foi rejeitado na Comissão de Constituição e Justiça da Câmara dos Deputados e nem mesmo chegou a ser votado pelo plenário. ${ }^{34}$

Durante debates legislativos acerca da reforma do Código de Processo Civil, entre 2010 e 2015, a Câmara dos Deputados aprovou a inclusão de um dispositivo prevendo que "o juiz ou o relator determinará que seja dada publicidade ao comparecimento informal, junto a ele, de qualquer das partes ou de seus representantes judiciais, ordenando o imediato registro nos autos mediante termo, do qual constarão o dia, o horário da ocorrência e os nomes de todas as pessoas que se fizeram presentes" ${ }^{35}$ Essa previsão foi originalmente justificada pelo princípio da publicidade dos atos oficiais estabelecido pela Constituição. A exposição de motivos explicitamente reconhecia a legitimidade das audiências privadas informais entre magistrados e advogados em razão de sua base legal, mas argumentava que a publicidade dos atos públicos "além de permitir o contraditório, reforça a aparência de imparcialidade e de independência dos

33 Projeto de Lei n. 6.732/2013, Deputado Camilo Cola - PMDB/ES, apresentação 07/11/2013.

${ }^{44}$ De acordo com a CCJ o PL 6.732/2913 violaria as "prerrogativas da advocacia" e, logo, seria inconstitucional porque "autonomia e independência da atuação dos advogados são defendidas na Constituição exatamente para proteger os interesses dos jurisdicionados". A CCJ argumentou ainda que "ao legislador não cabe patrulhar seja o exercício da advocacia, seja a liberdade de atuação do magistrado, que, em nosso ver, tem o direito de administrar seu juízo da forma que lhe parece apropriada". Projeto de Lei n. 6.732/2013, Deputado Camilo Cola - PMDB/ES, apresentação 07/11/2013. Parecer do Relator, Comissão de Constituição e Justiça e de Cidadania (CCJC), Deputado Cesar Colnago. Inteiro teor, 4/12/2014.

35 Substitutivo Câmara: Art. 190. O juiz ou o relator determinará que seja dada publicidade ao comparecimento informal, junto a ele, de qualquer das partes ou de seus representantes judiciais, ordenando o imediato registro nos autos mediante termo, do qual constarão o dia, o horário da ocorrência e os nomes de todas as pessoas que se fizeram presentes. $\S 1^{\mathrm{o}} \mathrm{O}$ juiz somente poderá tratar de qualquer causa na sede do juízo ou tribunal, salvo nas hipóteses previstas no art. 217. $\S$ $2^{\circ}$ As disposições deste artigo se aplicam aos casos de comparecimento informal de membro do Ministério Público e de agentes da administração pública. 
membros do Poder Judiciário" ${ }^{36}$. Na Câmara dos Deputados, sua aprovação foi justificada por tratar-se de "regra que concretiza três importantíssimos princípios republicanos: o juiz natural, ao preservar a imparcialidade do juiz; o contraditório, ao permitir a participação da outra parte quando a audiência houver sido agendada; e da publicidade, ao dar transparência à atuação do órgão jurisdicional" ${ }^{37}$ No fim das contas, o dispositivo foi rejeitado pelo Senado sem que os argumentos principiológicos em questão (imparcialidade, contraditório e publicidade/transparência) fossem considerados ${ }^{38}$.

Apesar dos recentes esforços legislativos apresentados acima, a atual legislação relativa às audiências informais privadas não detalha como como os despachos serão agendados e, tampouco, a maneira por meio da qual serão conduzidos. Além disso, dispositivos legais processuais que determinam a publicidade das audiências e dos atos processuais não têm sido aplicados para regular essa prática ${ }^{39}$. Como resultado, a forma de seu funcionamento acaba dependendo de cada magistrado.

No Supremo Tribunal Federal, o procedimento usual para aqueles que buscam ser recebidos por qualquer um dos ministros é mandar um e-mail para o endereço eletrônico destinado a esse fim do respectivo gabinete. ${ }^{40} \mathrm{~A}$ partir de então, a pessoa interessada deve aguardar uma resposta. Não existe, contudo, um critério público e uniforme acerca desse procedimento, incluindo parâmetros para selecionar quem será ou não recebido, ou prazos para o envio da solicitação e para a respectiva resposta por parte do tribunal. Com efeito, não é incomum que em um mesmo caso,

${ }^{36}$ Projeto de Lei n. 4110, de 2012, apensado ao Projeto de Lei n. 6.025, de 2005, Deputado Federal Rodrigo Garcia.

${ }^{37}$ Projeto de Lei n. 6.025, de 2005, ao Projeto de Lei n. 8.046, de 2010, ambos do Senado Federal, e outros, que tratam do "Código De Processo Civil" (Revogam A Lei No 5.869, de 1973), Parecer da Comissão Especial, Relator-Geral Deputado Sérgio Barradas Carneiro. Relator-Geral Substituto Deputado Paulo Teixeira, apresentado em 9/9/2012.

${ }^{38}$ Os membros da Comissão Especial para o Código e Processo Civil indicaram quatro razões para a rejeição: (i) o dispositivo iria contra o "intuito simplificador das rotinas processuais" do Código; (ii) a cláusula seria "vaga", vez que não deixaria "claro o que viria a ser 'comparecimento informal' (iii) violaria as prerrogativas dos advogados previstas no Estatuto da Advocacia; e (iv) independentemente da aprovação do referido dispositivo, os magistrados já seriam livres para, quando avaliassem conveniente, agendar dia e horário para que as partes contrárias pudessem se reunir conjuntamente. Projeto de Lei do Senado n. 166, de 2010, Parecer n. 956, de 2014 de 27 de Novembro de 2014 da Comissão Temporária do Código de Processo Civil, sobre o Substitutivo da Câmara dos Deputados (SCD) ao Projeto de Lei do Senado (PLS) n. 166, de 2010, que estabelece o Código de Processo Civil. Relator: Senador Vital do Rêgo, at 96-97.

${ }^{39}$ A esse respeito, o Código de Processo Civil dispõe em seu art. 368 que "A audiência será pública, ressalvadas as exceções legais". O Código Penal estabelece que: Art. 792. As audiências, sessões e os atos processuais serão, em regra, públicos e se realizarão nas sedes dos juízos e tribunais, com assistência dos escrivães, do secretário, do oficial de justiça que servir de porteiro, em dia e hora certos, ou previamente designados. (...).

${ }^{40}$ Note-se que não há nenhum regramento formal sobre o assunto, mas tão somente endereços de email para agendamento de audiências disponíveis no portal do STF: $<$ http://www.stf.jus.br/portal/cms/verTexto.asp?servico=sobreStfConhecaStfQuemEQuem> 
um ministro aceite ouvir determinada parte ou representante, enquanto outro ministro não. A esse respeito, há um problema adicional de transparência. A parte contrária nunca é pessoalmente notificada acerca da ocorrência de uma audiência privada relativa a um caso, sua realização e conteúdo não são registrados nos autos do caso e não existe um registro geral em que se possa buscar os despachos passados realizados no âmbito do STF.

É verdade que os ministros divulgam individualmente, online, suas agendas diárias. Entretanto, essa divulgação se dá de maneira extremamente assistemática. ${ }^{41}$ Primeiro, poucos ministros divulgam com regularidade suas reuniões, enquanto alguns deles não o fazem jamais. Segundo, muitas das agendas divulgadas contêm apenas informações genéricas, como a presença na sessão de determinada turma do STF, sem que haja qualquer informação acerca de reuniões com partes ou advogados. No segundo semestre de 2017, por exemplo, a média de divulgação de agendas do STF ficou em $40.81 \%$, sendo que do total das agendas divulgadas, $38.86 \%$ não continha qualquer menção a despacho com parte ou advogado. Em outras palavras, durante o período analisado, houve em média divulgação de agendas contendo informações sobre despachos em apenas $24.95 \%$ dos dias úteis. Veja-se o gráfico abaixo elaborado com base em levantamento que realizamos a partir das agendas que foram disponibilizadas no site do STF ao longo do segundo semestre de $2017^{42}$ :

41 A agenda dos ministros está disponível na aba, "Ïmprensa", no seguinte endereço: $<$ http://www.stf.jus.br/portal/agendaMinistro/listarAgendaMinistro.asp>. A agenda do ou da presidente, por sua vez, encontra-se aqui < http://www.stf.jus.br/portal/agendaPresidente/pesquisarAgendaPresidente.asp>.

${ }^{42} \mathrm{~A}$ pesquisa analisou todos os dias úteis durante o período de funcionamento do STF no segundo semestre de 2017, de $1^{\circ}$ de agosto a 19 de dezembro daquele ano. Embora em sete oportunidades alguns ministros tenham divulgado atividades ocorridas durante fins de semana e feriados, apenas dias úteis foram considerados para a elaboração do gráfico e dos dados indicados no presente artigo. 
Gráfico 1. Divulgação de Agendas em 2017.2

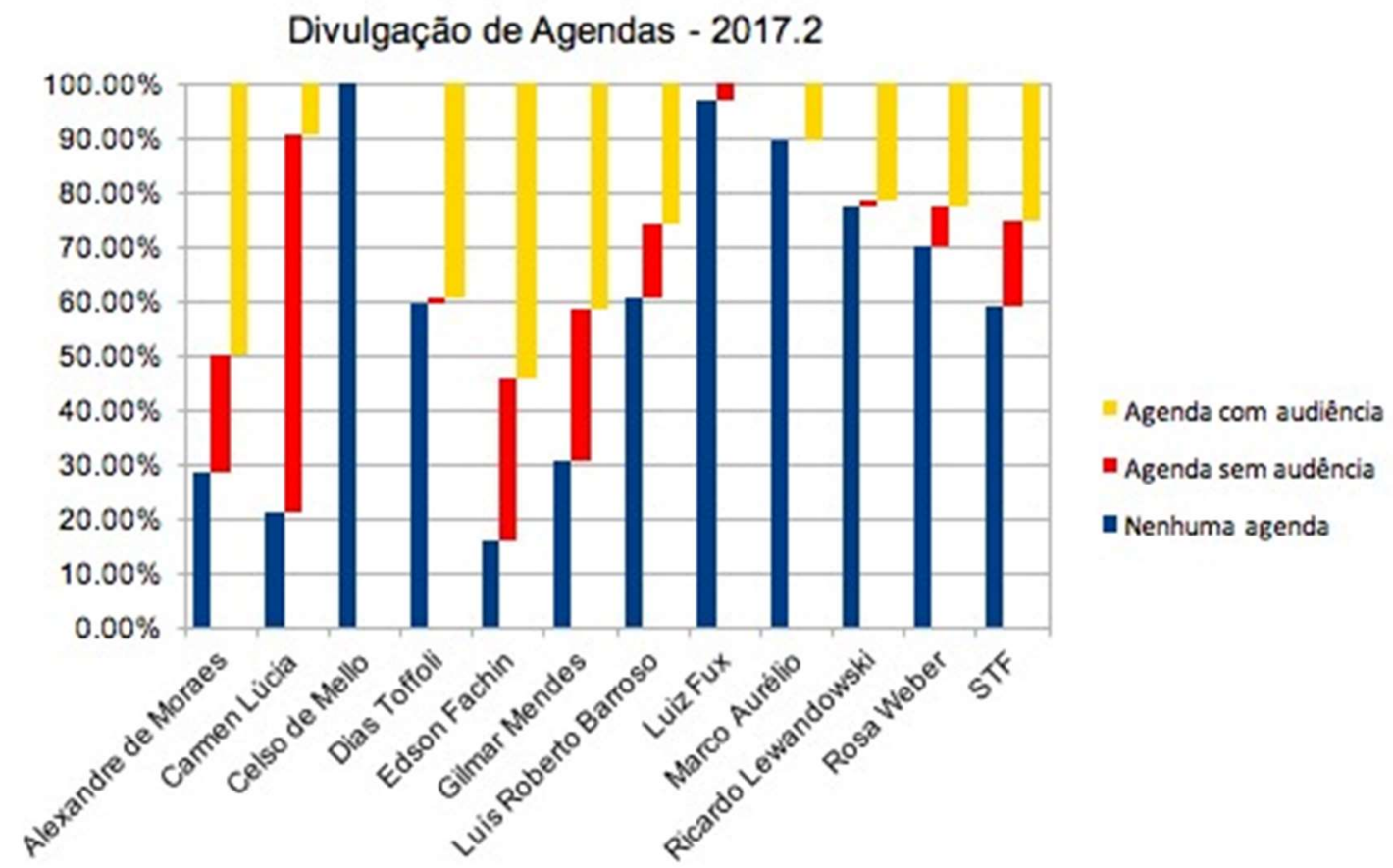

Note-se que, como o site do STF não disponibiliza um repositório de agendas pretéritas dos ministros, os dados acima foram obtidos por meio da alteração manual retroativa da barra de endereços do navegador de internet para cada data e cada ministro no segundo semestre de 2017.43 A falta de um arquivo oficial dificulta a pesquisa e prejudica as partes que se veem impossibilitadas de verificar despachos que tenham ocorrido no passado. A esse respeito, em dezembro de 2017, foi realizado no âmbito da presente pesquisa pedido de informações ao STF com

43 Por, exemplo, a barra de endereços para a Ministra Rosa Weber com a agenda atual (27 de junho de 2019) encontra-se em < http://www.stf.jus.br/portal/agendaMinistro/verAgendaMinistro.asp?data=27/06/2019\&siglaMini $\underline{\mathrm{stro}=\mathrm{RW}}>$. Para obter as agendas anteriores da referida ministra relativas ao período desejado (segundo semestre de 2017), replicou-se o endereço acima, alterando-se, de maneira manual, apenas a data. Assim, obteve-se acesso ao conteúdo publicado na ocasião, que não está, contudo, disponibilizado ao público no site atual do STF. Para evitar que problemas na navegação deixassem passar agendas efetivamente publicadas, a cada vez que se alterava retroativamente a barra de endereços, procedia-se a 30 "atualizações" da página. Além disso, os dados obtidos foram cruzados com imagens (prints) de versões anteriores da página com a listagem de agendas (<http://www.stf.jus.br/portal/agendaMinistro/listarAgendaMinistro.asp $>$ ) capturadas aleatoriamente e armazenadas pelo site Internet Archive WayBack Machine $<$ https://web.archive.org/>. Em razão dessas dificuldades, o levantamento dos dados foi realizado para um período limitado, tendo-se assegurado, contudo, que a composição do tribunal fosse a mesma que se apresenta atualmente. 
base na Lei de Acesso à Informação que, até a data de publicação deste artigo, não foi respondido ${ }^{44}$.

Adicionalmente, no período abarcado pelo levantamento e ainda hoje, as agendas disponibilizadas são, em regra, de datas anteriores, isto é, versam sobre dias já transcorridos e não sobre dias que estão por vir. Considerando, portanto, que as agendas são divulgadas de maneira retroativa, não é possível saber de antemão quem se reunirá com os ministros e quais casos serão discutidos. Como consequência, esses encontros ocorrem sem a presença da parte contrária, que muitas vezes sequer toma conhecimento de sua realização. É verdade que o ministro Dias Toffoli ao divulgar sua agenda, antes de assumir a presidência do STF, como regra, incluía ao lado da menção a despacho aviso que dizia: "O Gabinete está à disposição da(s) parte(s) contrária(s) para marcação de audiência referente ao processo em epígrafe", prática inaugurada pelo Ministro Joaquim Barbosa ${ }^{45}$. Mesmo adotando-se esse costume, a falta de antecedência na divulgação das agendas e a ausência de notificação pessoal das partes impede na prática que a parte adversa consiga estar presente no despacho de forma a exercer o contraditório e a ampla defesa. Como o conteúdo dos despachos não é disponibilizado, em eventual despacho ulterior a parte adversa não saberia que pontos foram abordados no encontro anteriormente realizado.

A esse respeito, em 2009, foi proposta uma emenda ao Regimento Interno do STF dispondo que "Nenhum Ministro é obrigado a receber parte ou seu advogado, senão na presença do advogado da parte contrária, ou, quando seja o caso, do representante do Ministério Público". Tal emenda, embora tenha sido subscrita por

${ }^{44} \mathrm{O}$ pedido foi realizado por meio da Central do Cidadão do portal do STF sob o número $444923 \mathrm{em}$ 15 de dezembro de 2017 e continha o requerimento das seguintes informações: "1. Quais os meios utilizados para realizar agendamento de audiências privadas com cada um dos ministros do Supremo Tribunal Federal? 2. Quais os critérios utilizados por cada ministro para autorizar a realização de audiência pessoal? 3. Qual a data quando, pela primeira vez, as agendas dos ministros do Supremo Tribunal Federal passaram a ser disponibilizadas online no sítio eletrônico do STF? 4. Por quais meios as agendas dos ministros do Supremo Tribunal Federal eram disponibilizadas antes de serem publicizadas online no sítio eletrônico do STF? 5. Quais os critérios utilizados por cada ministro para publicizar ou não suas agendas no sítio eletrônico do STF? 6. Quais os critérios utilizados por cada ministro para definir que tipos de compromisso integrarão a agenda que será disponibilizada online no sítio do STF? 7. Há certos tipos de compromisso, por pate de cada ministro, que não são incluídos na agenda disponibilizada no sítio eletrônico do STF? Em caso positivo, qual a razão dessa exclusão e quais os critérios utilizados para selecionar os compromissos que serão publicizados? 8. Com que antecedência as agendas dos ministros são publicizadas online no sítio eletrônico do STF?" E, ainda, dos seguintes documentos: “9. A íntegra do conteúdo de todas as agendas diárias de todos e cada um dos ministros do Supremo Tribunal Federal, em exercício ou não, a partir da data em que começaram a ser disponibilizadas no sítio eletrônico do STF até a presente data".

${ }^{45}$ Referido ministro incluía em sua agenda a seguinte orientação: “O Gabinete está à disposição da parte contrária para eventual agendamento de audiência sobre o mesmo processo, em igualdade de condições". 
sete dos onze ministros, não foi aprovada. ${ }^{46}$ Depois de divulgar seu voto contrário à emenda, em que considerava não ser cabível a imposição de "qualquer condição como é, no caso, a ligada à bilateralidade" ao "acesso aos membros do Judiciário" 47, o então presidente da Comissão para o Regimento Interno do STF, ministro Marco Aurélio, determinou a remessa do processo administrativo aos demais ministros integrantes da comissão (Cezar Peluso e Cármen Lúcia, que já haviam subscrito a proposta de emenda) e posterior devolução à Secretaria Executiva das Comissões Permanentes. A emenda nunca voltou a julgamento (FOLHA DE SÃO PAULO, 2009).

Finalmente, mesmo as poucas agendas efetivamente divulgadas no site do STF, além de irregulares, são incompletas: não listam audiências não-oficiais e reuniões informais que frequentemente ocorrem fora dos gabinetes dos ministros. Por exemplo, em um notório caso ocorrido em 2015, o então presidente do STF encontrou a presidente da república em uma reunião privada que não foi registrada em nenhuma das duas agendas oficiais (CAMAROTTI, 2015). Em janeiro de 2017, a imprensa cobriu um jantar não-oficial entre o presidente da república e um dos ministros que, inclusive, à época, era o presidente do Tribunal Superior Eleitoral, que julgaria, poucos meses depois, a idoneidade das contas da campanha eleitoral à presidência, que poderiam ter levado à deposição do presidente da república (MOURA; RODRIGUES, 2017). Atores privados também são beneficiados com encontros fora das dependências oficiais. Em janeiro de 2018, em jantar extraoficial promovido por portal jornalístico a então presidente do STF encontrou-se com representantes de diversas corporações, ocasião em que teria emitido opiniões sobre casos pendentes (NETZEL; KRÜGER; BARBIÉRI, 2018).

Se a seletividade social que ocorre por meio de despachos em gabinetes é extremamente problemática, os encontros que se sucedem fora da agenda dos ministros em ambientes não-oficiais são ainda mais graves. Nesses casos, o tratamento preferencial reflete-se não apenas na oportunidade de realizar o despacho, mas também nas circunstâncias em que se realiza: fora da agenda e fora do tribunal. A coexistência dos dois fenômenos- a realização de encontros oficiosos e a desregulamentação dos encontros oficiais - expõe ainda mais a influência assimétrica que diferentes grupos sociais estão aptos a exercer sobre o STF e a seletividade social de sua abertura.

Em resumo, no que tange à realização de audiências para despacho no STF, (i) nem todo advogado ou parte consegue um despacho depois de solicitá-lo; (ii) a decisão de receber ou não um advogado para um despacho ocorre de maneira altamente obscura e seletiva, segundo o critério pessoal de cada um dos ministros individualmente; (iii) a parte adversa nunca é notificada acerca da ocorrência de

\footnotetext{
${ }^{46}$ Subscreveram a proposta de emenda regimental os ministros Cezar Peluso, Eros Grau, Joaquim Barbosa, Menezes Direito, Ricardo Lewandowski, Cármen Lúcia e Carlos Ayres Britto.

${ }^{47}$ STF, Processo administrativo n. 335011, Pronunciamento Min. Marco Aurélio, 16 de fevereiro de 2009.
} 
um despacho futuro ou pretérito e, tampouco, tem prévio acesso a essa informação de forma a poder estar presente; (iv) a ocorrência e conteúdo de despachos pretéritos não são registrados nos autos do caso, no site do STF e tampouco disponibilizados via Lei de Acesso à Informação; (v) eventualmente o contato entre partes ou advogados e magistrados ocorre fora das dependências oficiais o que, em regra, não é registrado em suas agendas.

\section{PeRMeABILIDAde SOCIAL SELETIVA E VIOlAÇÃo DO ACESSO À JUSTIÇA, DA IGUALDADE E DA DEMOCRACIA}

Tanto a jurisprudência restritiva quanto aos legitimados ativos no controle abstrato quanto as práticas relativas aos despachos no STF funcionam como barreiras de permeabilidade seletiva, bloqueando para uns e viabilizando para outros o acesso ao tribunal. Nas duas hipóteses, não obstante a suposta neutralidade das regras processuais e procedimentais aplicáveis, na prática, "o Supremo escolhe quem ouvir e quando ouvir" 48 e, em caso afirmativo, como e em que condições.

Em ambos os casos, trata-se de um problema de acesso à justiça, mas, sobretudo, de igualdade. Isso porque regras e práticas que limitam o acesso à jurisdição constitucional recaem desigualmente sobre diferentes grupos sociais, afetando desproporcionalmente minorias e os grupos socialmente vulneráveis e marginalizados. Nesse sentido, uma aplicação igualitária e não enviesada das regras processuais é um pressuposto da ideia de acesso à justiça ${ }^{49}$.

Com relação ao 103, IX, a interpretação corporativa que limita entidade de classe a categoria profissional ou econômica desconsidera importantes formas contemporâneas de manifestação coletiva voltadas para a defesa de direitos fundamentais e relacionadas a diversas ordens de identidades e interesses (como os movimentos pacifista, de mulheres, ecológico, pela defesa dos animais, LGBTIQ+, negro etc) que vêm sendo compreendidas, de uma pespectiva técnica ${ }^{50}$

\footnotetext{
${ }^{48}$ A expressão é empregada por Fernando Leal (2019, p. 41-45) ao analisar o "mito da sociedade aberta de intérpretes" e a baixa utilidade prática da participação em audiências públicas perante o STF. Segundo o autor, "Falar não significa ser ouvido, e fazer-se ouvir não significa influenciar".

${ }^{49}$ Nesse sentido, veja-se: "Na minha definição, regras processuais podem facilitar o acesso ao impedir certos comportamentos individuais e institucionais. (...) Se uma regra diminui um efeito adverso em particular, então o acesso ao sistema é aumentado. Para facilitar a discussão. Eu categorizo esses efeitos adversos da seguinte maneira: (1) tático; (2) enviesado; (3) complexidade/custo. (...) Segundo, por enviesado quero dizer que as regras não devem ser aplicadas desigualmente. Não importa a localização da corte ou a identidade das partes, as regras devem ser as mesmas (COLEMAN, 2009, p. 264).

${ }^{50}$ Para uma visão política de noção de "classe": "Embora seja difícil, se não impossível, encontrar uma definição de Classe social que conte com o consenso dos estudiosos ligados a diversas tradições políticas e intelectuais, todos estão de acordo em pensar que as classes sociais são uma consequêencia das desigualdades existentes na sociedade" (CAVALLI, 1998, p. 169).
} 
ou não ${ }^{51}$, como classes. Dessa forma, tais estratos sociais são impedidos de protagonizar suas causas em sede de jurisdição constitucional e de veicular abertamente seus entendimentos constitucionais. Na melhor das hipóteses, se valem de intermediários para mascarar sua atuação constitucional.

Com relação à prática dos despachos, além da igualdade, outros princípios constitucionais são colocados em xeque. Em primeiro lugar, há um problema de publicidade e transparência na medida em que, como visto, as partes não têm acesso a informações sobre a ocorrência de despachos e, tampouco, sobre seus respectivos conteúdos. Além disso, as partes contrárias não são notificadas pessoalmente sobre a ocorrência de um despacho, esse acontecimento não é registrado nos autos dos processos e nem há um repositório disponível em que se possa buscar essa informação. Eventualmente, as agendas dos ministros são divulgadas no portal do STF. Entretanto, isso se dá a critério de cada ministro e de maneira irregular e assistemática, na maior parte das vezes deixando de fora informações sobre os despachos. Há ainda violação do contraditório, tendo em vista que a participação no despacho não é oportunizada à parte contrária. Finalmente, a violação da igualdade se reflete em um problema de imparcialidade e independência judiciais, na medida em que, em um mesmo processo, algumas partes poderão ter acesso pessoal e privado a seus julgadores enquanto outras não. Esse fenômeno é ainda mais grave quando tais encontros ocorrem extraoficialmente, fora do alcance de qualquer tipo de formalidade oficial ou controle público, ameaçando o fundamento básico da ideia de Estado de Direito segundo o qual as mesmas regras devem ser aplicadas independentemente de quem sejam partes.

Tanto na discussão sobre despachos quanto naquela acerca dos legitimados ativos para propositura de ações no controle abstrato de constitucionalidade, a violação do acesso à justiça e da igualdade justificam a demanda por equalização e democratização do acesso à jurisdição constitucional. No caso dos despachos, em que a própria imparcialidade judicial está em jogo, essa exigência se torna ainda mais incontornável.

Diante dessa pretensão, contudo, poderiam ser suscitadas objeções instantâneas de duas ordens. De um lado, argumentos relativos à lógica contramajoritária da Corte, que ensejaria uma "blindagem social" do Judiciário. De outro, razões relativas à carga de trabalho dos ministros. A necessidade de insulamento judicial

\footnotetext{
${ }^{51}$ 1. Na Roma antiga, cada uma das categorias entre as quais eram divididos os cidadãos, segundo sua riqueza 2. Cada um dos grupos ou divisão de uma série ou conjunto, categoria, seção, ordem 3. Categoria de cidadãos fundada nas distinções da lei ou na diferença de condição 4 . Categoria de pessoas fundada no mérito, importância ou capacidade individual 5 . Conjunto de pessoas que exercem a mesma profissão (...) 6. Categoria, grau, posto, hierarquia atribuída às pessoas ou às coisas classificadas segundo uma ordem de importância, qualidade, valor ou de preço 7. Grupo de pessoas que se distinguem das outras por suas ocupações, costumes, opiniões etc. (...) (HOUAISS; VILLAR, 2001, p. 736).
} 
e a sobrecarga de processos procuram, por caminhos diferentes, justificar um fechamento social da jurisdição constitucional.

Ambos os argumentos desviam o foco da discussão. Insinuam que o acesso ao STF por parte de grupos hoje excluídos dessa arena demandaria reformas profundas em sua estrutura, sem levar em conta os canais que atualmente existem. Para além de discutir a conveniência do aumento ou diminuição de vias de acesso ao tribunal, o argumento da permeabilidade social seletiva do STF questiona a distribuição desigual daquelas já existentes. Em outras palavras, explicita que a utilização de mecanismos de acesso por certos grupos sociais tem implicado a exclusão de outros e contesta os critérios supostamente neutros por meio dos quais os recursos limitados do tribunal são repartidos. A sobrecarga de trabalho do STF sem dúvida o obriga a realizar escolhas sobre quem será ouvido. Entretanto, é fundamental saber como essas escolhas são feitas, por meio de que procedimentos e, em ambos os casos, quais são seus impactos em termos de distribuição mais ou menos equânime do acesso ao tribunal.

Especificamente com relação ao insulamento judicial, entende-se que esse argumento parte de uma visão juriscêntrica que desconsidera o papel que atores externos já exercem na jurisdição constitucional, dentro e fora do processo. Essa concepção vem sendo questionada por inúmeros trabalhos que indicam que i) os entendimentos constitucionais são empreendimentos coletivos de cuja construção participam diversos atores e ii) os atores institucionais, mesmo os não eleitos, como magistrados, sofrem influência da sociedade em seu processo de tomada de decisão. De um lado, as chamadas teorias de "diálogos institucionais" 52 e de "diálogos sociais" 53 apontam a relação entre o Judiciário e, respectivamente, outros poderes e movimentos sociais e cidadãos na formação do significado constitucional, enfatizando a interação que ocorre, na prática, entre esses sujeitos. De outro lado, estudos sobre comportamento judicial indicam que elementos extrajurídicos condicionam a maneira como os juízes decidem seus casos ${ }^{54}$.

Do ponto de vista normativo, essa visão do direito é cega ao que atores e instituições externas ao tribunal podem oferecer em termos de interpretação constitucional e de oportunidades para os ministros identificarem e corrigirem problemas em suas posições ao longo do tempo. No limite, rejeita a participação de sujeitos extraestatais como parceiros em uma empreitada coletiva para a construção do sentido da Constituição. Ao mesmo tempo, naturaliza o franqueamento do acesso ao tribunal a certos grupos que funcionam como "detentores oficiosos ou invisíveis do poder" ${ }^{\prime \prime 5}$. Nesse sentido, as práticas descritas são sintomas de um problema maior.

\footnotetext{
52 Sobre o assunto, veja-se Mendes (2011) e Brandão (2011).

${ }^{53}$ Sobre o assunto, veja-se Gomes (2016).

${ }^{54}$ Sobre o tema, Molhano Ribeiro e Werneck Arguelhes (2013, p. 85-121).

${ }^{55}$ A expressão é de Loewenstein (1976, p. 423).
} 
A injustificada obstaculização a certos grupos do acesso à jurisdição constitucional vai de encontro à ideia de democracia e à possibilidade de o cidadão participar da conformação do projeto constitucional e de nele operar mudanças como coautor em uma empreitada coletiva que envolve passado, presente e futuro (BALKIN, 2004, p. 493). O fechamento seletivo das instituições em uma democracia viola tanto a exigência de autogoverno, segundo a qual cabe aos membros de uma sociedade o poder de determinar seu funcionamento e controlar o exercício do poder por seus mandatários, quanto a noção de pluralismo, segundo a qual "a luta de ideias deve processar-se de uma forma tendencialmente desregulamentada e indeterminada quanto ao seu desfecho" (MACHADO, 2002, p. 367).

Nesse ensejo, mesmo instituições cujos membros não são eleitos, como o Poder Judiciário, devem legitimar-se à luz desses preceitos. Diante do pluralismo das sociedades contemporâneas e da "dificuldade contramajoritária" (BICKEL, 1986) que recai sobre o Poder Judiciário, exige-se a justificação racional das decisões judiciais a partir da consideração dos dados e argumentos apresentados (MENDES, 2013).

A participação de todos auxilia a evidenciar os conflitos por detrás das demandas constitucionais, dando voz aos diferentes pontos de vista e evitando o silenciamento de grupos sociais marginalizados. Ao se atribuir uma face aos interesses contrapostos, revelando do que e por quem são compostos, fortalece-se a noção de que a democracia pressupõe uma multiplicidade de discursos, instituições e formas de vida (MOUFFE, 2000, p. 94-97). Ao mesmo tempo, a abertura permite questionar a parcialidade dos debatedores (ampliando suas perspectivas), revelar informações privadas (o que faz com que a decisão final seja melhor informada) e promover a "iluminação recíproca" (SILVA, 2013, p. 557-584) entre seus participantes (incentivando resultados que não seriam encontrados por nenhum deles individualmente). ${ }^{56}$ Além disso, estimulam-se práticas e procedimentos que visam à participação daqueles que sofrerão os efeitos das decisões (BENHABIB, 1996, p. 73), incentivando uma penetração da sociedade nas intuições e em suas instâncias decisórias. Valoriza-se, ainda, a construção de uma "conversa pública" (BENHABIB, 1996, p. 74), com ênfase no desenvolvimento de um processo justo e de um debate mais inclusivo e plural.

Da necessidade de participar democraticamente das decisões estatais vinculantes, extrai-se um "direito fundamental de participação ativa nos procedimentos estatais decisórios" (CABRAL, 2004, p. 10), que não se limita à mera participação (que poderia ser viabilizada por outros mecanismos), mas inclui uma

\footnotetext{
${ }^{56}$ Fearon (1998). Outros argumentos, segundo o autor, corroboram que a discussão é positiva porque "força ou induz um modo particular de justificar demandas, legitima a última escolha, é desejável por si mesma, faz decisões melhores à luz do ótimo de Pareto e também e, termos de justiça distributiva, promovem um consenso maior, aperfeiçoam as qualidades morais e intelectuais dos participantes. Tais argumentos são listados na introdução da obra em ao longo da qual são mais profundamente desenvolvidos".
} 
exigência de paridade de armas dos diferentes sujeitos sociais na conformação dos significados constitucionais. A demanda por equalização do acesso à jurisdição constitucional abarca, portanto, a exigência de paridade de armas e constitui um elemento que condiciona o próprio acesso à justiça, entendido como a "habilidade, na prática, de uma parte reconhecer seus direitos jurídicos e de persegui-los ou defendê-los adequadamente" (CAPPELLETTI; GARTH, 1977, p. 183). Do mesmo modo, a democratização dos diferentes mecanismos de acesso à jurisdição constitucional funciona como uma salvaguarda da imparcialidade e da independência dessa arena e, no limite, do próprio Estado de Direito.

\section{CONCLUSÃo}

Nos últimos anos, o STF tem se apresentado como uma Corte aberta que valoriza a participação da sociedade na jurisdição constitucional. ${ }^{57} \mathrm{Em}$ diversas decisões, diferentes ministros têm referendado ideias nessa linha, como, por exemplo, a de que "a melhor postura hermenêutica é compreender a interpretação constitucional como uma obra complexa e inacabada, cuja construção decorre do trabalho de diversas mãos" processos judiciais de grande significado para toda a sociedade cumpre uma função de integração extremamente relevante no Estado de Direito"59 e é um "supedâneo da legitimidade [do STF]"60. Em outras oportunidades, vão além ao defender um modelo procedimental que pressupõe não apenas "amplo acesso e participação de sujeitos interessados (...), [mas também] a possibilidade efetiva de o Tribunal Constitucional contemplar as diversas perspectivas na apreciação da legitimidade de um determinado ato questionado". ${ }^{61}$ Em outros contextos, propondo uma perspectiva ainda mais simbiótica da relação entre sociedade e corte, chegam a sustentar posições controversas como a de que o STF desempenha uma função representativa (BARROSO, 2018, p. 2171-2228) e que suas decisões têm de refletir os "anseios da sociedade" (TUROLLO; CASADO, 2018).

Apesar da intenção manifestada pelo STF, suas portas não estão abertas para todos. Com efeito, como o presente artigo buscou demonstrar, longe de ser democrática e igualitária, a permeabilidade social do STF opera de maneira seletiva ao impedir o acesso de certos grupos ao à jurisdição constitucional ao mesmo tempo em que a franqueia a outros, em violação às ideias de acesso à justiça, igualdade, democracia e, no limite, do próprio Estado de Direito.

\footnotetext{
57 Para isso, em inúmeras oportunidades ministros tem se referido à categoria de "sociedade aberta de intérpretes da Constituição" de Peter Häberle. Nesse sentido, ao analisar o papel de amicus curiae e audiência pública no STF, Fernando Leal (2019, p. 41-45) chama atenção para o que denomina "mito da sociedade aberta de intérpretes da Constituição Supremo".

58 Decisão monocrática no MS 29494, Rel. Min. Roberto Barroso, julg. 11.04.2018.

${ }^{59}$ Decisão monocrática na ADI 4832, Rel.: Min. Rosa Weber, julg. 28.01.2013.

60 STF, ADI 4029, Pleno, Rel. Min. Luiz Fux, julg. 08.03.2012, voto do relator.

${ }^{61}$ Decisão monocrática na ADI 3842, Rel. Min. Gilma Mendes, julg. 03.12.2009.
} 
A seletividade social do STF atua por meio de diversos mecanismos formais e informais amparados em regras processuais e procedimentais aparentemente neutras. Ao analisar dois desses mecanismos, o presente artigo buscou, por um lado, evidenciar a dimensão política de tais regras, contribuindo para a discussão acerca das diferentes maneiras por meio das quais os tribunais constitucionais promovem ou deixam de promover os direitos fundamentais, especialmente de minorias políticas. Por outro lado, o trabalho procurou revelar as variadas formas por meio das quais o fenômeno da permeabilidade social seletiva se desenvolve, assim como suas graves consequências.

Dos casos analisados, um tem origem em uma criação jurisprudencial restritiva e o outro em uma série de práticas não regulamentadas. A alteração e o aprimoramento de ambos dependem apenas do próprio STF. No primeiro caso, o da legitimidade ativa para o controle abstrato de constitucionalidade, bastaria uma revisão de sua jurisprudência no sentido já apontado nas recentes decisões monocráticas proferias pelos ministros Marco Aurélio e Roberto Barroso. Ao ampliar o entendimento acerca das entidades legitimadas, o STF contribuiria para a democratização do acesso à jurisdição constitucional e para o fortalecimento do projeto constitucional plural e inclusivo de 1988.

No segundo caso, o das audiências privadas entre partes e ministros do STF, um bom começo seria a retomada do processo administrativo em que se propõe a necessária participação da parte adversa nos despachos e cujo julgamento está suspenso há uma década. Na ocasião, outras dimensões da questão devem ser igualmente regulamentadas, como a consolidação dos procedimentos para solicitação de despacho e os critérios para sua concessão, assim como a divulgação e o arquivo da ocorrência das referidas audiências para consulta pública. Essa medida, além de corroborar o compromisso do tribunal com o acesso à justiça, a paridade de armas e o contraditório, constituiria uma refutação a expedientes que operam às escondidas, "por trás dos panos". Com efeito, esse compromisso com a transparência e o Estado de Direito serviria, ainda, como exemplo oportuno para os demais juízes e tribunais do país.

\section{REFERÊNCIAS}

ARGUELHES, Diego Werneck. Poder não é querer: preferências restritivas e redesenho institucional no Supremo Tribunal Federal pós-democratização. Universitas Jus (UniCEUB Law Journal), v. 25, n. 1, 2014.

BALKIN, Jack. Respect-worthy: Frank Michelman and the legitimate Constitution. Tulsa Law Review, v. 39, 2004. 
BARROSO, Luís Roberto. Contramajoritário, Representativo e Iluminista: Os papeis dos tribunais constitucionais nas democracias contemporâneas. Revista Direito e Práxis, v. 9, n. 4, 2018, p. 2171-2228.

BARROSO, Luís Roberto. Uniões homoafetivas: reconhecimento jurídico das uniões estáveis entre parceiros do mesmo sexo. In: BARROSO, Luís Roberto. O novo Direito Constitucional brasileiro: contribuições para a contrução teórica e prática da jurisdição constitucional brasileira. Belo Horizonte: Fórum, 2013.

BENHABIB, Seyla. Toward a deliberative model of democracy legitimacy. In: BENHABIB, Seyla (Ed.). Democracy and difference. Princeton: Princeton University Press, 1996.

BICKEL, Alexander. The least dangerous branch: the Supreme Courts and the bars of Politics. 2 ed. New Heaven/London: Yale University Press, 1986.

BRANDÃO, Rodrigo; NUNES, Daniel Capecchi. O STF e as entidades de classe de âmbito nacional: a sociedade civil e seu acesso ao controle concentrado de constitucionalidade. Revista de Direito da Cidade, v. 10, n. 1, 2018.

BRANDÃO, Rodrigo. Supremacia judicial versus diálogos constitucionais: a quem cabe a última palavra sobre o sentido da Constituição? Rio de Janeiro: Lumen Juris, 2011.

BURBANK, Sephen B. Procedure, Politics and Power: The Role of Congress. Faculty Scholarship, Paper 501, 2004. Disponível em:

$<$ http://scholarship.law.upenn.edu/faculty_scholarship/501>. Acesso em: 25 fev. 2020.

CABRAL, Antonio do Passo. Pelas asas de Hermes: a intervenção do amicus curiae, um terceiro especial. Revista de Processo, ano 29, n. 117, 2004.

CAMAROTTI, Gerson. Fora da agenda, Dilma tem encontro reservado com Lewandowski em Portugal. 9 jul. 2015. Disponível em <http://g1.globo.com/politica/blog/blog-do-camarotti/post/fora-da-agenda-dilmatem-encontro-reservado-com-lewandowski-em-portugal.html>. Acesso em: 25 fev 2020. 
CAPPELLETTI, Mauro; GARTH, Bryant. Access to justice: the newest wave in the worldwide movement to make rights effective. Buffalo Law Review, v. 27, 1977.

CARVALHO, Ernani. Revisão abstrata da legislação e judicialização da política no Brasil: especificidade e seletividade. 2005. Tese (Doutorado em Ciência Política). Universidade de São Paulo, 2005.

CAVALLI, Alessandro. Classe. In: BOBBIO, Norberto; MATTEUCCI, Nicola; PASQUINO, Gianfranco. Dicionário de Política. Tradução Carmen C. Varriale et ai. Brasilia: Ed. UNB, 1998.

COLEMAN, Brooke. Recovering Access: Rethinking the Structure of Federal Civil Rulemaking. New Mexico Law Review, v. 39, n. 2, p. 262, 2009.

COSTA, Alexandre Araújo da. BENVINDO, Juliano Zaiden. (Coord.) A quem interessa o controle de constitucionalidade: O Descompasso entre Teoria e Prática na Defesa dos Direitos Fundamentais. Relatório de Pesquisa da Universidade de Brasília, 2013.

COVER, Robert M. For James Wm. Moore: Some Reflections on a Reading of the Rules. The Yale Law Journal, v. 84, n. 4, 1975, p. 718-740.

FEARON, James D. Deliberation as discussion. In: ELSTER, Jon. (Org.) Deliberative Democracy. Deliberative Democracy. Cambridge University Press, 1998.

FERREIRA, Letícia de Oliveira Catani Ferreira; GERAIGE NETO, Zaiden. Da possibilidade de interpretação extensiva do inciso IX do artigo 103 da Constituição Federal mediante proteção processual coletiva. SCIENTIA IURIS, v. 22, n. 1, 2018, p. 101-133.

FOLHA DE SÃO PAULO. Naufraga proposta do STF contra assédio de advogados. 18 mar. 2009. Disponível em <https://www1.folha.uol.com.br/fsp/ brasil/fc1803200906.htm>. Acesso em: 25 fev. 2020.

FOLHA DE SÃO PAULO. Sepúlveda Pertence derruba obrigatoriedade do uso de vestido ou saia no plenário do STF: Supremo libera calça para mulheres. 24 maio 1997. Disponível em: <https://www1.folha.uol.com.br/fsp/brasil/fc240526.htm>. Acesso em: 25 fev. 2020. 
FREIRE, Alonso Freire. Desbloqueando os canais de acesso à jurisdição constitucional do STF: Por que não também aqui uma revolução de direitos?. In: SARMENTO, Daniel (Org). Jurisdição constitucional e política, 2015, p. 591-640.

GOMES, Juliana Cesario Alvim. Behind the Scenes: Informal private hearings between lawyers and judges in Brazil under the Inter-American Court of Human Rights' jurisprudence, no prelo.

GOMES, Juliana Cesario Alvim. O Supremo Tribunal Federal em uma perspectiva de gênero: mérito, acesso, representatividade e discurso. Revista Direito e Práxis, v. 7, 2016, p. 652-676.

GOMES, Juliana Cesario Alvim. Por um Constitucionalismo Difuso: cidadãos, movimentos sociais e o significado da Constituição. Salvador: JusPodivm, 2016.

GOMES, Juliana Cesario Alvim. Por um Constitucionalismo Difuso: cidadãos, movimentos sociais e o significado da Constituição. Dissertação (Mestrado em Direito). Universidade do Estado do Rio de Janeiro, 2014.

GUIMARÃES, Aline Lisboa Naves. Participação Social no Controle de Constitucionalidade. 2009. Dissertação de mestrado em Direito. Universidade de Brasilia, 2009.

HOUAISS, Antônio; VILLAR, Mauro de Salles. Dicionário Houaiss de Língua Portuguesa. Rio de Janeiro: Objetiva, 2001.

LEAL, Fernando. O mito da sociedade aberta de intérpretes da Constituição. FALCÃO, Joaquim et. al. (Orgs.) O Supremo e o Processo Eleitoral. Belo Horizonte: Letramento; Casa do Direito; FGV Direito Rio; Supra; Jota, 2019.

LEITE, Carina L. N. S. Diálogos Sociais no STF: o art. 103, X, da Constituição e a participação da sociedade civil no controle concentrado de constitucionalidade. In: BARROSO, Luís Roberto; MELLO, Patrícia Perrone Campos. (Orgs.). A República que ainda não foi: trinta anos da Constituição de 1988 na visão da Escola de Direito Constitucional da UERJ. Belo Horizonte: Forum, 2018. 
LEITE, Carina L. N. S. Os diálogos sociais no STF: as audiências públicas, o amicus curiae e a democratização da jurisdição constitucional brasileira. 2014. Dissertação (estrado em Direito.) Universidade do Estado do Rio de Janeiro, 2014.

LIMA, Flávia Danielle Santiago. tribunal. Ativismo e Autocontenção no Supremo Tribunal Federal: uma proposta de delimitação do debate. 2013. Tese (Doutorado em Direito). Universidade Federal de Pernambuco, 2013.

LOEWENSTEIN, Karl. Teoría de la Constitución. Trad. Alfredo Gallego Anabitarte. Barcelona: Editora Ariel, 1976.

MACHADO, Jónatas E. M. Liberdade de Expressão: dimensões constitucionais da esfera pública no sistema social. Cimbra: Coimbra editora, 2002.

MENDES, Conrado Hübner. Constitutional Courts and Deliberative Democracy. Oxford: Oxford University Press, 2013.

\section{MENDES, Conrado Huibner. Direitos Fundamentais, Separação de Poderes e} Deliberação. São Paulo: Saraiva, 2011.

MIGALHAS. Formalismo no STF exige cuidados ao se vestir. 25 de fev. 2019. Disponível em: <https://www.migalhas.com.br/Quentes/17,MI296950,31047Formalismo+no+STF+exige+cuidados+ao+se+vestir>. Acesso em: 25 fev. 2020.

MINOW, Martha. Politics and Procedure. In: KAIRYS, David (ed.). The Politics of Law: A Progressive Critique. 3. ed. New York: Basic Books, 1998.

MOLHANO RIBEIRO, Leandro; WERNECK ARGUELHES, Diego. Preferências, Estratégias e Motivações: Pressupostos institucionais de teorias sobre comportamento judicial e sua transposição para o caso brasileiro. Revista Direito e Práxis, v. 4, n. 2, 2013, p. 85-121.

MOUFFE, Chantal. The Democratic Paradox. London: Verso, 2000.

MOURA, Rafael; RODRIGUES, Eduardo. Temer recebe Gilmar Mendes em jantar no Palácio do Jaburu. 22 jan. 2017. Disponível em: <http://politica.estadao.com.br/ noticias/geral,temer-e-gilmar-mendes-discutem-quadro-politico-em-jantar-nojaburu,70001637801>. Acesso em : 25 fev. 2020. 
NETZEL, Mateus; KRÜGER, Ana; BERBIÉRI, Luiz Felipe. STF se apequena se revisar prisão em $2^{2}$ Instância por Lula, diz Cármen Lúcia. 30 jan. 2018. Disponível em: <https://www.poder360.com.br/justica/stf-se-apequena-se-revisar-prisao-em2a-instancia-por-lula-diz-carmen-lucia/>. Acesso em 25 fev. 2020.

PEREIRA, Jane Reis Gonçalves. O Judiciário como Impulsionador dos Direitos Fundamentais: Entre Fraquezas e Possibilidades. Revista da Faculdade de Direito da UERJ, v. 29, 2016.

RESNIK, Judith. The Domain of Courts. Faculty Scholarship Series. Paper 913, 1989. Disponível em: <http://digitalcommons.law.yale.edu/fss_papers/913>.

Acesso em: 25 fev. 2020.

SARMENTO, Daniel. Dar voz a quem não tem voz: Por uma nova leitura do art. 103, IX, da Constituição. In: VIEIRA, Oscar Vilhena; GLEZER, Rubens (Orgs.). A razão e o voto: diálogos constitucionais com Luís Roberto Barroso. São Paulo: Editora FGV Direito SP, 2017.

SILVA, Virgílio Afonso da. Deciding without deliberating. International Journal of Constitutional Law, v. 11, 2013, p. 557-584.

TUROLLO JR, Reynaldo; CASADO, Letícia. Devemos proferir decisão que represente anseio da sociedade, diz Fux. 2 out. 2018. Disponível em: $<$ https://www1.folha.uol.com.br/poder/2018/10/devemos-proferir-decisao-querepresente-anseio-da-sociedade-diz-fux.shtml>. Acesso em: 25 fev. 2020.

VIANNA, Luiz Werneck et al. A judicialização da política e das relações sociais no Brasil. Rio de Janeiro: Ed. Revan, 1999. 